\title{
Relationship between Quality of Work Life of Medical Staff and Quality of Patient Care
}

\author{
Amjad Mohammadi-Bolbanabad ${ }^{1}$, Barzan Shirkhani ${ }^{2,}{ }^{*}$, Samira Mohammadi ${ }^{3}$, Heshmatollah Asadi ${ }^{1}$, Abas Aghaei ${ }^{1}$ \\ ${ }^{1}$ Clinical Research Development Center, Imam Khomeini Hospital, Kermanshah University of Medical Sciences, Kermanshah, IR Iran \\ ${ }^{2}$ Shahid Chamran Hospital of Kangavar, Kermanshah University of Medical Sciences, Kermanshah, IR Iran \\ ${ }^{3}$ Department of Reproductive Health, School of Nursing \& Midwifery, Tehran University of Medical Sciences, Tehran, IR Iran
}

*Corresponding Author: Barzan Shirkhani, M.Sc. of Health Services Management, Shahid Chamran Hospital of Kangavar, Kermanshah University of Medical Sciences, Kermanshah, Iran. Mobile: +989181304497, Email: barzan.shirkhani87@gmail.com

Received: 19 Nov. 2015; Accepted: 11 Jan. 2016; Online Published: 28 May. 2016

\begin{abstract}
Background: Nowadays, quality of patient care is one of the major and important concerns of health care delivery which is extremely dependent on the medical staff.

Objectives: The purpose of this study was to investigate the relationship between Quality of Work Life (QWL) and quality of patient care.

Methods: This study was a descriptive-analytic study based on correlation which was conducted in the educational hospitals of Kermanshah. A total of 320 medical staffs were selected for the study. Quality of Work Life and Quality of Patient Care questionnaires were used to collect the data. For data analysis, descriptive statistics, person correlation coefficient, t-test and multivariate regression were used by using SPSS $_{16}$

Results: Data analysis showed that the Quality of Work Life of medical staffs was in a medium level. Our findings indicate that there is a significant, negative relationship between stress at work and quality of patient care ( $\mathrm{P}$-value $=0.001 \& \mathrm{r}=-0.247)$ and there is a significant, positive relationship between control \& job satisfaction and quality of patient care (P-value $=0.001 \& \mathrm{r}=0.217$ ). Results of multivariate regression analysis showed that stress at work net account for $6 \%$ of the variance of the quality of patient care.

Conclusion: Focusing on improving the working conditions of medical staffs can be incredibly useful in increasing the quality of health care.
\end{abstract}

Keywords: Quality of Health Care, Stress, Medical Staff

\section{Background}

Today, the quality of patient care is a major concern in provision of health care [1]. The quality of medical care depends upon the people who work in the system; the most valuable resource in the health system is not the latest technology or the most modern facilities, but the workers who are the human resources [2]. Health care providers should have incentives to promote patient safety and quality of patient care through professional ethics and work norms [3]. These workers are the second victims of low quality services that harm patients [4,5]. Health care is complex and many factors affect the quality of patient care. Healthcare managers and policy-makers look for solutions to increase the functioning of health and treatment organizations [3].

Many variables and factors affect the quality of patient care, including the quality of the work life of employees which can affect the quality of service [6] cause minor accidents, and lead to job dissatisfaction and desertion by personnel [7]. The quality of work life is comprehensive and increasing employee satisfaction and education helps them adapt to change [8]. Studies have found that the effect of different aspects of the quality of work that influence the quality of patient care include life organizational variables such as organizational conditions [9], occupational stress [10], organizational support from the medical staff [11], workload [12], job satisfaction [7, 13], and occupational burnout $[9,14,15]$. Quality of work life can affect staff performance [16] and job engagement [17] and the factors also predict the quality of organizational service.

\section{Objective}

The present study determined the quality of work life as expressed by health workers in the study population and its association with the quality of patient care.

\section{Methods}

This correlational and cross-sectional descriptive study was conducted with the participation of the medical staff (physicians, nurses and midwives] of the hospitals of Kermanshah University of Medical Sciences in 2013. The sample size of 320 participants was selected using the following formula:

The sample size was chosen at a $95 \%$ confidence interval (CI) and 90\% statistical power. The results were considered statistically significant with a correlation coefficient of $\geq 0.2$. The following formulas were used to determine the sample size of 320 employees:

$$
\begin{aligned}
& \mathrm{Z}=\frac{1}{2} \operatorname{Ln} \frac{1+p_{0}}{1-p_{0}}=\frac{1}{2} \operatorname{Ln} \frac{1+0.2}{1-0.2}=0 / 203 \\
& n=\frac{\left(\mathrm{Z}_{1-\alpha_{2}}+\mathrm{Z}_{1-\mathrm{B}}\right)^{2}}{\mathrm{Z}_{0}^{2}}+3=\frac{(1 / 96+1 / 65)^{2}}{(0 / 203)^{2}}+3=320
\end{aligned}
$$

The sample size was based on the size of the seven hospitals and the medical staff at each hospital. They were categorized according to the position and gender of participants and were selected from each division (physicians, nurses, midwives) in proportion to division size. The data collection tool included two questionnaires: 
A) The quality of work life questionnaire included the categories of job control and satisfaction, work conditions, general wellbeing, work-life balance, stress at work, and control at work. The questionnaire was based on a 5-point Likert scale from 0 (strongly disagree) to 4 (strongly agree) for positive items and were measured at the ordinal level for changes in distance by combining all items. The questionnaire was based on Van Laar's study [18] and was translated by Shabannejad. The content validity was assessed by the professors and experts at Tehran University of Medical Sciences and the experts of the Department of Health Management and Economics and the Ministry of Health and Medical Education. The reliability of the questionnaire was measured using the test-retest method and showed a 95\% correlation coefficient and Cronbach's alpha of 0.78 for internal association [19].

B) The patient care quality questionnaire included the Shanafelt self-report questionnaire of quality of health care (2002) with eight questions for the categories of viewpoint and behavior of medical staff towards quality of patient care. The questionnaire was completed by self-report of the medical staff based on a 5-point Likert scale as: never (4), once a year (3), several times a year (2), every month (1) and every week (0) [15] and were measured at the ordinal level for changes in distance by combining all the items together. The content validity of the translated questionnaire was assessed by the professors and experts of the University of Medical Sciences and was confirmed. To assess the validity of the questionnaire, a pilot study was conducted on 30 participants. The results scored a Cronbach's alpha of 0.74 for measurement of internal association.

To better compare the results of this study with other studies, both questionnaires were adjusted for all aspects after summing the scores on a scale of 0-100. SPSS v. 16 was used for data analysis to describe the data and descriptive statistics (mean, etc.). The T-test (bivariate comparison), ANOVA (multivariate comparison), Pearson's correlation, and multiple regression were used to assess the relationship between the variables.

\section{Results}

Of the total of 320 health workers, $26.2 \%(n=84)$ were physicians, the rest were non-physician (nurses, midwives, etc.), and $41.3 \%(n=132)$ were male. Table 1 shows that among the factors affecting quality of work life, stress at work had the highest mean (59.29\%) and work-home relationships had the lowest mean $(46.06 \%)$. The mean quality of work life was $54.29 \%$. The mean quality of patient care was $56.42 \%$ and moderate. The mean quality of patient care for non-physician staff (nurses, midwives, etc.) was $56.73 \%$ and for physicians was $56.12 \%$.

The T-test results indicate there was no significant difference between job description and quality of work life $(\mathrm{P}=0.01)$. The quality of work life of physicians (average of $57.11 \%$ ) was higher than the quality of life for nonphysician staff (nurses, midwives; average of 53.28). The quality of work life of employees did not differ between genders $(\mathrm{P}=0.121)$. There was also no significant difference between physicians and non-physician staff for quality of patient care $(\mathrm{P}=0.523)$.

The results indicate that there was a significant relationship between the quality of patient care and employee occupational stress and satisfaction. The relationship between employee occupational stress and quality of patient care was negative at an intensity of -0.246 $(\mathrm{P}=0.001)$ and the relationship between employee job satisfaction and quality of patient care was direct at an intensity of $0.217(\mathrm{p}=0.001)$. The other aspects and the total quality of work life were not significantly associated with patient care (Table 2).

Table 1. Mean quality of work life of respondents $(n=320)$

\begin{tabular}{lccccccc}
\hline $\begin{array}{c}\text { Quality of work } \\
\text { life }\end{array}$ & $\begin{array}{c}\text { Job } \\
\text { satisfaction }\end{array}$ & $\begin{array}{c}\text { Work } \\
\text { conditions }\end{array}$ & $\begin{array}{c}\text { Work } \\
\text { control }\end{array}$ & $\begin{array}{c}\text { Public health } \\
\text { status }\end{array}$ & $\begin{array}{c}\text { Occupational } \\
\text { stress }\end{array}$ & $\begin{array}{c}\text { Work-home } \\
\text { relationship }\end{array}$ & $\begin{array}{c}\text { Total quality of } \\
\text { work life }\end{array}$ \\
\hline Mean (scale $0-100)$ & 52.92 & 53.89 & 54.53 & 53.71 & 59.29 & 46.04 & 54.29 \\
Standard deviation & 12.57 & 19.90 & 12.15 & 10.79 & 9.12 & 7.26 & 11.38 \\
\hline
\end{tabular}

Table 2. Correlation of test results for quality of work life versus quality of patient care $(n=318)$

\begin{tabular}{|c|c|c|c|c|c|c|c|c|}
\hline \multirow{4}{*}{$\begin{array}{l}\text { Quality of } \\
\text { patient care }\end{array}$} & \multirow[b]{3}{*}{ Intensity } & \multicolumn{7}{|c|}{ Quality of Work Life } \\
\hline & & $\begin{array}{c}\text { Job } \\
\text { satisfaction }\end{array}$ & $\begin{array}{c}\text { Work } \\
\text { conditions }\end{array}$ & $\begin{array}{l}\text { Work } \\
\text { control }\end{array}$ & $\begin{array}{c}\text { Public health } \\
\text { status }\end{array}$ & $\begin{array}{l}\text { Occupational } \\
\text { stress }\end{array}$ & $\begin{array}{l}\text { work-home } \\
\text { relationship }\end{array}$ & $\begin{array}{l}\text { Total quality of } \\
\text { work life }\end{array}$ \\
\hline & & 0.217 & 0.045 & 0.045 & 0.075 & -0.246 & 0.064 & 0.058 \\
\hline & p-value & 0.001 & 0.427 & 0.419 & 0.183 & 0.001 & 0.253 & 0.304 \\
\hline
\end{tabular}

Stepwise multiple regression analysis in which the variables are ranked according to the intensity of correlation with the dependent variable (patient care) and the variables with the highest interaction remained in the model. Regression analysis of the factors determining quality of patient care showed that of the independent variables entered into the final regression model, only occupational stress remained and accounted for approximately $6 \%$ of changes in the quality of patient care (Table 3 and Table 4).

Table 3. Multivariate regression of quality of patient care

\begin{tabular}{ccccc}
\hline $\begin{array}{c}\text { Durbin- } \\
\text { Watson }\end{array}$ & $\begin{array}{c}\text { Std. } \\
\text { Error }\end{array}$ & Adjusted $\mathbf{R}^{\mathbf{2}}$ & $\mathbf{R}^{\mathbf{2}}$ & $\mathbf{R}$ \\
\hline 1.8 & 13.39 & 0.06 & 0.062 & 0.246 \\
\hline
\end{tabular}

Table 4. Independent variables remaining in model

\begin{tabular}{cccccc}
\hline Variable & B & Std. B & Beta & T & p-value \\
\hline Intercept & 36.25 & 4.52 & - & 8.007 & 0.001 \\
Job stress & -0.372 & 0.082 & -0.220 & -4.517 & 0.001 \\
\hline
\end{tabular}

\section{Discussion}

The quality of work life of the medical staff at the hospitals of Kermanshah University of Medical Sciences was moderate, which is not satisfactory. Arab et al. [20] and Shabaninejad et al. [19] studied the quality of work life of physicians in Iran and similarly found it to be moderate in quality. There was no significant difference between quality of work life of medical staff by gender, although the quality of life was higher in men than women. This result is 
consistent with findings of Shabaninejad et al. [19], Arab et al. [20] and Eker et al. [21].

No significant relationship was found between the quality of work life versus job category of personnel. The quality of work life of physicians was higher than of nonphysicians (nurses and midwives), which may be the result of differences in income and the increased freedom and more flexible shifts of physicians than of midwives.

Only two aspects (job stress and satisfaction) of quality of work life were significantly associated with the quality of patient care. Job stress was inversely (negatively) related to the quality of patient care; this is in line with the findings of Park et al. [10] that showed job stress is a threat to quality of patient care and safety. Job satisfaction had a direct relationship with quality of patient care, which is consistent with the findings of Havlovic [7] and Nantesopat et al. [13]. The results of linear regression showed that job stress was the only predictor of the quality of patient care and predicted $6 \%$ of quality of patient care.

\section{Conclusion}

The quality of work life may affect the quality of work and commitment [6]. The findings of the present study suggest that the quality of work life of the staff at the hospitals of Kermanshah University of Medical Sciences was not good and could affect the quality of patient care as related to job stress and satisfaction. Policy-makers and managers in the health field concerned with increasing the quality of health care should increase job satisfaction and improve the quality of health care by improving the quality of work life. The quality of medical care is a constant concern for the medical staff, because they are the second victims of low-quality service; thus, it appears necessary to attend to the quality of work life of employees to improve this issue.

\section{Acknowledgments}

The expert advice of the Department of Clinical Research Development at Imam Khomeini Hospital in Kermanshah was highly appreciated. We would also like to thank the healthcare personnel who completed the questionnaires and provided suggestions despite their heavy workloads.

\section{Authors' Contributions}

All authors contributed equally in the preparation of this paper.

\section{Conflict of Interest}

No conflict of interest has been declared by the authors.

\section{References}

1. Stratton KM, Blegen MA, Pepper G, Vaughn T. Reporting of medication errors by pediatric nurses. $\mathrm{J}$ Pediatr Nurs. 2004;19(6):385-92. [DOI]
2. Bodenheimer TS, Grumbach K. Understanding Health policy: a clinical approach. 4th Ed; New York, (NY): McGraw-Hill Companies, Inc; 2004.

3. Khalilzadeh H, Hemmati Maslakpak M, Mohaddesi H, Zare Fazlollahi Z. Attitude among Urmia Medical University health workers about patient safety. J Urmia Nurs Midwifery Facul. 2013;11(8):606-13. Persian.

4. Wu AW. Medical error: the second victim. West $\mathbf{J}$ Med. 2000;172(6):358. [DOI]

5. Scott SD, Hirschinger LE, Cox KR, McCoig M, Brandt J, Hall LW. The natural history of recovery for the healthcare provider "second victim" after adverse patient events. Qual Saf Health Care. 2009;18(5):325-30. [DOI]

6. van de Looij F, Benders J. Not just money: quality of working life as employment strategy. Health Manpow Manage. 1995;21(3):2733. [DOI]

7. Havlovic SJ. Quality of work life and human resource outcomes. Industrial Relations: A Journal of Economy and Society. 1991;30(3):469-79. [DOI]

8. Saraji GN, Dargahi H. Study of quality of work life (QWL). Iran J Public Health. 2006;35(4):8-14.

9. Spânu F, Băban A, Bria M, Lucăcel R, Dumitraşcu DL. A Study of Health Professionals' Burnout and Quality of Care in Romania. Procedia-Social Behav Sci. 2013;84:1149-53. [DOI]

10. Park YM, Kim SY. Impacts of Job Stress and Cognitive Failure on Patient Safety Incidents among Hospital Nurses. Saf Health Work. 2013;4(4):210-5. [DOI]

11. Farzianpour F, Fouroshani AR, Vahidi RG, Arab M, Mohamadi A. Investigating the relationship between organizational social capital and service quality in teaching hospitals. Am J Econ Bus Admin. 2011;3(2):425. [DOI]

12. Chui MA, Look KA, Mott DA. The association of subjective workload dimensions on quality of care and pharmacist quality of work life. Res Social Adm Pharm. 2014;10(2):328-40. [DOI]

13. Nantsupawat A, Srisuphan W, Kunaviktikul W, Wichaikhum OA, Aungsuroch Y, Aiken LH. Impact of nurse work environment and staffing on hospital nurse and quality of care in Thailand. J Nurs Scholarsh. 2011;43(4):426-32. [DOI]

14. Poghosyan L, Clarke SP, Finlayson M, Aiken LH. Nurse burnout and quality of care: cross-national investigation in six countries. Res Nurs Health. 2010;33(4):288-98. [DOI]

15. Shanafelt TD, Bradley KA, Wipf JE, Back AL. Burnout and selfreported patient care in an internal medicine residency program. Ann Intern Med. 2002;136(5):358-67. [DOI]

16. Shahbazi B, Shokrzadeh S, Bejani H, Malekinia E, Ghoroneh D. A survey of relationship between the quality of work life and performance of Department Chairpersons of Esfahan University and Esfahan Medical Science University. Procedia-Social Behav Sci. 2011;30:1555-60. [DOI]

17. Kanten S, Sadullah O. An empirical research on relationship quality of work life and work engagement. Procedia-Social Behav Sci. 2012;62:360-6. [DOI]

18. Van Laar D, Edwards JA, Easton S. The Work-Related Quality of Life scale for healthcare workers. J Adv Nurs. 2007;60(3):325-33. [DOI]

19. Shabaninejad H, Arab M, Rashidian A, Zeraati H, Bahrami S Quality of working life of Family Physicians in Mazandaran. Hakim Res J. 2012;15(2):178-84. Persian.

20. Arab M, Shabaninejad H, Rashidian A, Rahimi A, Purketabi K. A survey on working life quality of specialists working in affiliated hospitals of TUMS. Hosp J. 2013;11(4):19-24. Persian.

21. Eker L, Tuzun EH, Daskapan A, Surenkok O. Predictors of job satisfaction among physiotherapists in Turkey. J Occup Health. 2004;46(6):500-5.[DOI] 